\title{
Salinity Resistance of Seven Varieties of Madura Corns on Early Stage of Growth
}

\author{
Kelik P. W. Sukma \\ Dept. Agrotechnology, Fac. Agriculture \\ Universitas Islam Madura \\ Pamekasan, East Java, Indonesia \\ keliksukma@gmail.com \\ Isdiana Suprapti \\ Dept. Agribussines, Fac. Agriculture \\ Universitas Trunojoyo Madura \\ Bangkalan, East Java, Indonesia \\ ana.utm@gmail.com
}

\author{
Budi Setiadi Daryono \\ Faculty of Biology \\ Universitas Gadjah Mada \\ Yogyakarta, Indonesia \\ bs_daryono@mail.ugm.ac.id \\ Purnomo \\ Faculty of Biology \\ Universitas Gadjah Mada \\ Yogyakarta, Indonesia \\ nomo@ugm.ac.id
}

\begin{abstract}
Seven of sixteen varieties of Madura Corns (Guluk-Guluk, Manding, Talango, Duko, Elos, Deber and Tambin), were planted on beach area. This research objectives was to study character the germination of maize in saline media. The corns were planted on saline media $(0,100$, and $200 \mathrm{mM} \mathrm{NaCl}$ ), conducted by using randomized block design with 4 replications. Significant differences between treatments were determined Duncan's Multiple Range Test at 5\% level. The germination parameters were measured until seven days after treatment such as Full Germination Percent (FGP), Mean Germination Time (MGT), Germination Index (GI), and Salt Tolerance Index (STI). Seedling growth on saline media by wick system hydroponic was measured at 21 days after planting. The parameter measured were seedling height, growth ratio and proline content. The result was salinity decreased germination ability and seedling growth. Duko and Tambin had the highest salinity tolerance on germination, but Manding had the highest on seedling growth.
\end{abstract}

Keyword-corn, germination,saline, seedling growth

\section{INTRODUCTION}

Corn (Zea mays L.) is used as food and feed ingredients. The corns is distinguished by seeds and endosperm character, the environment, harvest time, and their usefulness. Based on harvest time, the corn can be divided into short (75-90 days), medium (90-120 days) and long maturity'(more than 120 days). Corn growing environment consists of tropical lowlands $(<1,000$ masl), subtropical lowlands, mid-altitude subtropics (1,000-1,600 masl), and tropical highlands ( $>1,600$ masl) [1].

There are many varieties of maize in Madura Islands, Indonesia. [2] mentioned 16 varieties, such as ; Tambin-1, Tambin-2, Delima, Cetek, Dheber, Parsong, Krajekan, Elos, Talango, Kangean, Guluk-guluk, Dlubeng, Raddin, Manding, Geltik and Duko. Four cultivars that have higher production potential than other Madura maize, namely Tambin-1, Delima, Tambin-2 and Raddin. Krajekan have shortest harvest time. Var. Manding have the potential as salinity resistant corn [3]

There are 7 varieties include Manding, were planted on beach area, such as Guluk-Guluk, Manding, Talango, Duko, Elos, Deber and Tambin. This research objectives was to study character of maize in saline media on early stage of growth (germination and seedling growth).

\section{METHODS}

\section{A. Plant material and Research Design}

Maize from the research of [2], were var. Elos (El.), Manding (Md.), Guluk-Guluk (Gl.), Duko (Du.), Dheber (Dh.), Talango (Tl.) and Tambin (Tb.). Seeds with similiar size and weight were selected to obtain homogenous germination rate. Seeds were surface sterilized in $2 \%(\mathrm{v} / \mathrm{v})$ sodium hypochloride for $10 \mathrm{~min}$ and washed with distilled water. Thirty seeds were placed on filter papers which contained different salt concentrations and located in $15 \mathrm{~cm}$ diameter steril petridishes.

The experiment was conducted by using randomized block design with 4 replications. Significant differences between treatments were determined by Duncan's Multiple Range Test at 5\% level.

\section{B. Germination Assays}

Salt stress was realised by germinated on $\mathrm{NaCl}$ solution $0.100 \mathrm{mM}$ and $200 \mathrm{mM}$. All treatments were replicated four times each cultivars and $\mathrm{NaCl}$ content. Germination were compared at room temperature $\left( \pm 27^{\circ} \mathrm{C}\right)$ in the dark. The germination seeds were counted everyday for seven days. Seeds were considered to have germinated when the emergence of radicles $\geq 2 \mathrm{~mm}$ [3], [4]

Full Germination Percent (FGP) was calculated by equation

$$
\mathrm{FGP}=\frac{\text { number of germinated seeds }}{\text { total seeds number }} \times 100 \%
$$

The Mean Germination Time (MGT) was calculated everyday for each replication used the equation [4], [5], and [6]

$$
\text { MGT }=\frac{\text { number of seeds newly germinated at day D }}{\text { number of all germinated seeds }}
$$

Germination Index (GI) was calculated by equation [4], [7], [8], [9].

$$
\mathrm{GI}=\sum\left(\frac{\text { the number of seeds germinated on } \mathrm{D} \text { day }}{\text { number of days up to } \mathrm{D} \text { day }}\right)
$$


Salt Tolerance Index (STI) on germination was calculated by equation [7].

$$
\mathrm{STI}=\frac{\text { germination/growth in a particular treatment }}{\text { germination/growth in the control }}
$$

\section{Seedling Assays}

The seedlings were cultivated by wick system hydroponic. The media used [10] added by $\mathrm{NaCl} 0.100 \mathrm{mM}$ and $200 \mathrm{mM}$. It had same reprication with germination treatment. Plants height measured at 21 days after cultivated. Plants leaves at 21 days after cultivated were cut and measured Proline content, quantified according to the method of nynhidrin [11].

\section{RESULTS AND DISCUSSION}

\section{A. Germination Character}

Based on the results, salinity treatment decreased the value of FGP, GI and STI of all local Madura maize varieties (Table 1). Var. Duko and Elos could germinated in $200 \mathrm{mM} \mathrm{NaCl}$, which were not significantly different with the control $(0 \mathrm{mM} \mathrm{NaCl})$. Manding and Dheber could germinated, but significantly different with the control. Corn var. Guluk-Guluk, Talango, and Tambin could not germinated in $200 \mathrm{mM} \mathrm{NaCl}$. The STI of each cultivars at the germination stage showed genotypic variation. At $0 \mathrm{mM}$ and $100 \mathrm{mM}$, all varieties showed not significantly differences. it were significantly different on $200 \mathrm{mM}$. Duko had the highest salt tolerance index but it was not significantly different with Elos. Guluk-Guluk, Talangoh and Tambin had the lowest STI.

Those results similar with previous research that salt stress can reduce germination ability [7], [12], [13], [14], [15], [16], [17], [18].

In $0 \mathrm{mM} \mathrm{NaCl}$ medium, seeds germinated normally cause water and another nutrient normally absorbed. Increasing $\mathrm{NaCl}$ concentration in medium can decrease the osmotic potential that make prevent the uptake of water (necessary for mobilization of nutrient required for germination). Increasing $\mathrm{NaCl}$, also make the ions $\left(\mathrm{Na}^{+}\right.$or $\mathrm{Cl}^{-}$) may be toxic to the embryo [7]. Finally, its inhibits or slows the rate of germination and thus decreased germination percentage [17], [19].

\section{B. Seedlling Character}

On seedling growth, Tabel 2 show that salt stress reduced corns height. Manding was the tallest on $200 \mathrm{mM}$ $\mathrm{NaCl}$ and Duko was the shortest. Manding also had highest plant height ratio (in $200 \mathrm{mM} / 0 \mathrm{mM} \mathrm{NaCl}$ ) and the lowest was Duko (Figure 1). The reducing of seedling growth also reported by another research [20], [21], [22], [23]. According to previous research [24], salt stress reduced plant growth by induced osmotic stress, ion toxicity, and nutritional imbalance. Osmotic stress means high concentration of salt in the root zone limits water potential of solution and reduces plant root water conductivity, make reducing of cell membrane permeability and influx of water to the plant. ions toxicity made by sodium, chloride, sulphate and bicarbonates. Nutriotional imbalance, occur in the cells was caused by excessive accumulation of $\mathrm{Na}^{+}$and $\mathrm{Cl}^{-}$, reduces the uptake of other mineral nutrients, such as $\mathrm{K}^{+}, \mathrm{Ca}^{2+}$ and $\mathrm{Mn}^{2+}$. Those factors caused metabolism disruption, then inhibit seedling growth.

Table 1. Germination Character of Seven Corn Varieties on Difference Salinity Level

\begin{tabular}{|c|c|c|c|c|}
\hline \multirow{2}{*}{ Parameter } & \multirow{2}{*}{ Var. } & \multicolumn{3}{|c|}{ Salt Treatment } \\
\hline & & $0 \mathrm{mM}$ & $100 \mathrm{mM}$ & $200 \mathrm{mM}$ \\
\hline \multirow[t]{7}{*}{ FGP (\%) } & El. & $100 \mathrm{~d}$ & $92.5 \mathrm{~cd}$ & $80 \mathrm{bcd}$ \\
\hline & Md. & $100 \mathrm{~d}$ & $100 \mathrm{~d}$ & $10 \mathrm{a}$ \\
\hline & Gu. & $100 \mathrm{~d}$ & $95 \mathrm{~cd}$ & $0 \mathrm{a}$ \\
\hline & Du. & $100 \mathrm{~d}$ & $100 \mathrm{~d}$ & $90 \mathrm{~cd}$ \\
\hline & Dh. & $95 \mathrm{~cd}$ & $90 \mathrm{~cd}$ & $7.5 \mathrm{a}$ \\
\hline & Tl. & $100 \mathrm{~d}$ & $75 \mathrm{bc}$ & $0 \mathrm{a}$ \\
\hline & $\mathrm{Tb}$. & $82.5 \mathrm{bcd}$ & $67.5 \mathrm{~b}$ & $0 \mathrm{a}$ \\
\hline \multirow[t]{7}{*}{ MGT (d) } & El. & $2.65 \mathrm{bc}$ & $4.67 \mathrm{def}$ & $5.00 \mathrm{ef}$ \\
\hline & Md. & $2.40 \mathrm{~b}$ & 4.05 bcdef & 4.00 bcdef \\
\hline & $\mathrm{Gu}$. & $3.18 \mathrm{bcde}$ & $4.60 \mathrm{def}$ & $0.00 \mathrm{a}$ \\
\hline & Du. & 3.65 bcdef & $4.68 \mathrm{def}$ & $5.45 \mathrm{f}$ \\
\hline & Dh. & 4.00 bcdef & 4.38 cdef & $3.00 \mathrm{bcd}$ \\
\hline & Tl. & 3.95 bcdef & $5.02 \mathrm{cdef}$ & $0.00 \mathrm{bcd}$ \\
\hline & $\mathrm{Tb}$. & 3.81 bcdef & 3.56 bdef & $0.00 \mathrm{a}$ \\
\hline \multirow[t]{7}{*}{ GI } & El. & $9.63 \mathrm{~h}$ & $4.31 \mathrm{~d}$ & $3.02 \mathrm{bc}$ \\
\hline & Md. & $7.79 \mathrm{~g}$ & $4.95 \mathrm{de}$ & $0.21 \mathrm{a}$ \\
\hline & Gu. & $5.85 \mathrm{ef}$ & $4.18 \mathrm{~cd}$ & $0.00 \mathrm{a}$ \\
\hline & Du. & 5.79 ef & $4.58 \mathrm{de}$ & $2.50 \mathrm{~b}$ \\
\hline & Dh. & $5.86 \mathrm{ef}$ & $4.74 \mathrm{de}$ & $0.13 \mathrm{a}$ \\
\hline & Tl. & $6.71 \mathrm{fg}$ & $2.84 \mathrm{~b}$ & $0.00 \mathrm{a}$ \\
\hline & $\mathrm{Tb}$. & $5.93 \mathrm{ef}$ & $2.95 \mathrm{bc}$ & $0.00 \mathrm{a}$ \\
\hline \multirow[t]{7}{*}{ STI } & El. & $1.00 \mathrm{c}$ & $0.93 \mathrm{c}$ & $0.80 \mathrm{c}$ \\
\hline & Md. & $1.00 \mathrm{c}$ & $1.00 \mathrm{c}$ & $0.10 \mathrm{ab}$ \\
\hline & $\mathrm{Gu}$. & $1.00 \mathrm{c}$ & $0.95 \mathrm{c}$ & $0.00 \mathrm{a}$ \\
\hline & Du. & $1.00 \mathrm{c}$ & $1.00 \mathrm{c}$ & $0.90 \mathrm{c}$ \\
\hline & Dh. & $1.00 \mathrm{~b}$ & $0.96 \mathrm{c}$ & $0.33 \mathrm{~b}$ \\
\hline & Tl. & $1.00 \mathrm{c}$ & $0.75 \mathrm{c}$ & $0.00 \mathrm{a}$ \\
\hline & Tb. & $1.00 \mathrm{c}$ & $0.81 \mathrm{c}$ & $0.00 \mathrm{a}$ \\
\hline
\end{tabular}

Note : number followed by same letter on row and column, not significantly different on DMRT 5\%.

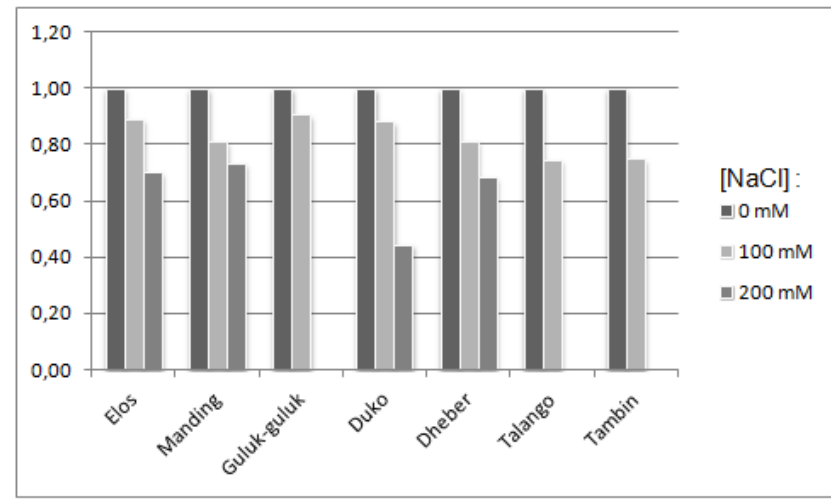

Figure 1. Shoot Height Ratio of Madura Corn on Salt Stress

Table 2 also showed that proline level of all varieties increased when $\mathrm{NaCl}$ concentration also increased. But Talangoh was decreased on $200 \mathrm{mM} \mathrm{NaCl}$. The highest $\mathrm{NaCl}$ concentration was Manding, could indicate more tolerance to salt stress than others. Increasing of prolin content on salt stress also reported by [25], [26], [27] and [28]. Plants produce proline to block reactive oxygen species (ROS). ROS was substance in plant (such as 
hydrogen peroxide, superoxide, singlet oxygen, and hydroxyl radical) that produced while plants was under stress. Overproduction of ROS increased lipid peroxidation, protein degradation and DNA mutation [29]. In higher plants proline increased to stabilize cell membran [30].

Table 2. Seedling Character of Seven Corn Varieties on Difference Salinity Level

\begin{tabular}{|c|c|c|c|c|}
\hline \multirow{2}{*}{ Para-meter } & \multirow{2}{*}{ Var. } & \multicolumn{3}{|r|}{ Salt Treatment } \\
\hline & & $0 \mathrm{Mm}$ & $100 \mathrm{mM}$ & $200 \mathrm{mM}$ \\
\hline \multirow[t]{7}{*}{ Height } & El. & 33.00 defghi & 29.00 cdefgh & $23.00 \mathrm{cdefg}$ \\
\hline & Md. & 38.63 ghi & 31.25 defghi & 27.78 cdefgh \\
\hline & $\mathrm{Gu}$. & 33.60 fghi & 30.40 defgh & $0.00 \mathrm{a}$ \\
\hline & Du. & 32.25 defghi & 27.25 bcdefg & $14.10 \mathrm{~b}$ \\
\hline & Dh. & 31.83 defghi & 24.83 bcdef & 20.88 bcde \\
\hline & Tl. & $40.38 \mathrm{i}$ & 29.68 cdefgh & $0.00 \mathrm{a}$ \\
\hline & Tb. & $36.35 \mathrm{ghi}$ & 27.05 bcdefg & $0.00 \mathrm{a}$ \\
\hline \multirow[t]{7}{*}{$\begin{array}{l}\text { Growth } \\
\text { ratio }\end{array}$} & El. & 1.54 & 1.50 & 1.71 \\
\hline & Md. & 1.49 & 1.15 & 1.58 \\
\hline & $\mathrm{Gu}$. & 1.87 & 1.78 & 1.70 \\
\hline & Du. & 1.46 & 1.43 & 1.50 \\
\hline & Dh. & 1.54 & 1.30 & 1.84 \\
\hline & Tl. & 1.50 & 1.41 & 1.93 \\
\hline & $\mathrm{Tb}$. & 1.53 & 1.90 & 1.41 \\
\hline \multirow[t]{7}{*}{ Proline } & El. & $2.31 \mathrm{~b}$ & 138.921 & $180.68 n$ \\
\hline & Md. & $74.36 \mathrm{~g}$ & $99.65 \mathrm{~h}$ & $279.42 \mathrm{~s}$ \\
\hline & $\mathrm{Gu}$. & $16.41 \mathrm{~d}$ & $132.50 \mathrm{k}$ & 195.49 o \\
\hline & Du. & $1.45 \mathrm{a}$ & $119.79 \mathrm{i}$ & $253.13 \mathrm{r}$ \\
\hline & Dh. & $6.14 \mathrm{c}$ & $131.58 \mathrm{j}$ & $210.65 \mathrm{p}$ \\
\hline & Tl. & $6.35 \mathrm{c}$ & $55.92 \mathrm{f}$ & $22.92 \mathrm{e}$ \\
\hline & $\mathrm{Tb}$. & $2.98 \mathrm{~b}$ & $179.36 \mathrm{~m}$ & $237.92 \mathrm{q}$ \\
\hline
\end{tabular}

Note : number followed by same letter on row and column, not significantly different on DMRT 5\%.

\section{CONCLUSION}

Salinity resistance of seven varieties of Madura corns were difference. Stress decrease germination ability and seedling growth of all varieties. Maize var. Duko and Elos had the highest salinity tolerance on germination but Var. Manding had the highest on seedling growth.

\section{ACKNOWLEDGMENT}

Thanks for my wife and all my family, and Mr. Sony Suwarsono that has gave many advice to this article. Also thanks to Ministry of Research, Technology and High Education that had given research grant in fiscal year 2018.

\section{REFERENCES}

[1] Iriany, R. N., M. Yasin, M. H. G. dan A. M. Takdir, ”Asal, Sejarah, Evolusi, dan Taksonomi Tanaman Jagung", Balai Penelitian Tanaman Serealia, Maros, 2007.

[2] Amzeri, A., "Karakterisasi dan Koleksi Plasma Nutfah Untuk Mencegah Erosi Genetik Jagung Lokal Madura", Laporan Akhir Kegiatan Penelitian Hibah Desertasi Doktor, 2010, unpublished.

[3] Sharma, R. K., and S. Sharma, "Effect of storage and coldstratification on seed physiological aspects of Bunium persicum : A threatened medicinal herb of Trans-Himalaya", Int. J. Bot. Vol. 6(2), pp 151-156, 2010.

[4] Aliu, S., I. Rusinovci, S. Fetahu, B. Gashi, E. Simeonovska, L. Rozman, "The effect of salt stress on the germination of maize (Zea mays L.) seeds and photosynthetic pigments", Acta agriculturae Slovenica, Vol. 105 - 1, pp 85-94, 2015
[5] Moradi D.P., F. Sharif-Zadeh, M. Janmohammadi, "Influence of priming techniques on seed germination behavior of maize inbred lines (Zea mays L.)", Journal of Agricultural and Biological Sciences, Vol. 3(3), pp 22-25, 2008.

[6] Soltani E., F. Gahderi-Far., C. C. Baskin, J. M. Baskin, "Problem with using mean germination time to calculate rate of seed germination", Australian Journal of Botany, 2015.

[7] Khayatnezhad M. and R. Gholamin, "Effects of salt stress levels on five maize (Zea mays L.) cultivars at germination stage", African Journal of Biotechnology, Vol. 10(60), 2011.

[8] Ruan S, Q. Xue, K. Tylkowska, "The Influence of Priming on Germination of Rice (Oryza sativa L.) Seeds and SeedlingEmergence and Performance in Flooded Soil", Seed Sci. Technol. Vol. 30, pp 61-67, 2002.

[9] Atık M, O. Karagüzel, S. Ersoy, "Effect Of Temperature On Germination Characteristics Of Dalbergia Sissoo Seeds", Journal of the faculty of Agriculture, Akdenız Unıversity, Vol. 20(2), pp 203210, 2007

[10] Hoagland, D. R. And D. I. Arnon, "The water-culture methods for growing plants without soil", California Agricultural Experiment Station, Circular 347, 1950.

[11] Bates, L. S., R. P. Waldren, I. D. Teare, "Rapid determination of free proline water stress studies. Plant and soil”, Vol 39(1), 1973. https://link.springer.com/article/10.1007/BF00018060

[12] Sholihah, N. F. and T. B. Saputro, "Respon tanaman jagung (Zea mays L.) varietas Manding terhadap cekaman salinitas $(\mathrm{NaCl})$ secara In Vitro", Jurnal Sains dan Seni ITS, Vol. 3(2), hal 23373520, 2016.

[13] Saboora A, and K. Kiarostami, "Salinity $(\mathrm{NaCl})$ tolerance of wheat genotypes at germination and early seedling growth, Pak. J. Biological Sci., Vol. 9(11), pp 2009-2021, 2006.

[14] Carpici, E. B. N. Celik, G. Bayram, "Effects of salt stress on germination of some maize (Zea mays L.) cultivars", African Journal of Biotechnology, Vol. 8 (19), pp. 4918-4922, 2009.

[15] Rahman M, S. S. Kayani, S. Gul, "Combined Effects of Temperature and Salinity Stress on Corn Sunahry Cv.", Pak. J. Biological Sci., Vol. 3(9), pp 1459-1463, 2000.

[16] Gill P. K., A. D. Sharma, P. Singh, S. S. Bhullar, "Osmotic stresinduced changes in germination, growth and soluble sugar changes of Sorghum bicolor (L.) seeds", Bulg. J. Plant Physiol., Vol. 28, pp $12-25,2002$

[17] Almodares A, M. R., M. R. Hadi, B. Dosti, "Effects of salt stres on germination percentage and seedling growth in sweet sorghum cultivars”, J. Biological Sci., Vol. 7(8), pp 1492-1495, 2007.

[18] Blanco F. F. , M. V. Folegatti, H. R. Gheyi, P. D. Fernandes, "Emergenceand growth of corn and soybean under saline stress", Sci. Agric. Piracicaba, Braz., Vol. 64(5), pp 451-459, 2007.

[19] Rahnama A., R. A. James, K. Poustini, R. Munns, "Stomatal conductance as a screen for osmotic stress tolerance in durum wheat growing in saline soil", Functional Plant Biology, Vol. 37 (3), pp 255-263, . 2010. http://dx.doi.org/10.1071/FP09148.

[20] Netondo G. W., J. C. Onyango, E. Beck, "Sorghum and salinity. II. Gas exchange and chlorophyll fluorescence of sorghum under salt stress", Crop Science, Vol 44, 2004.

[21] Bilgin, O., I. Baser, K. Z. Korkut, A. Balkan, N. Saglam, "The impacts on seedling root growth of water and salinity stress in maize (Zea mays indentata STURT.)", Bulgarian Journal of Agricultural Science, Vol. 14(3), pp 323-320, 2008.

[22] Bakht, J., M. Shafi, Y. Jamal, H. Sher, "Response of Maize (Zea mays L.) to seed priming with $\mathrm{NaCl}$ and salinity stress", Spanish Journal of Agricultural Research, Vol. 9(1), pp 251-261, 2011.

[23] Puvanitha, S., and S. Mahendran, "Effect of salinity on plant height, shoot and root dry weight of selected rice cultivars, Sch. J. Agric. Vet. Sci., Vol. 4(4), pp 126-131, 2017. 
[24] [24] Hassan Abbasi, H. , M. Jamil, A. Haq, S. Ali, R. Ahmad, Z. Malik, Parveen, "Salt stress manifestation on plants, mechanism of salt tolerance and potassium role in alleviating it: a review", Zemdirbyste-Agriculture, Vol. 103( 2). Pp 229-238, 2016.

[25] Dogan M., R. Tipirdamaz, Y. Demir, "Salt resistance of tomato species grown in sand culture", Plant, Soil and Environment, Vol. 56, pp 499-507, 2010.

[26] Nabati J., M. Kafi, A. Nezami, P. R. Moghaddam, A. Masoumi, M. Z. Mehrjerdi, "Effect of salinity on biomass production and activities of some key enzymatic antioxidants in burning bush (Kochia scoparia)", Pakistan. Journal of Botany, Vol. 43, pp 539548, 2011.

[27] Huang, Z., 1. Zhao, D. Chen, M. Liang, Z. Liu, H. Shao, X. Long, "Salt stress encourages proline accumulation by regulating proline biosynthesis and degradation in Jerusalem artichoke plantlets, PLoS One, Vol. 8(4), pp e62085, 2013.

[28] Balkrishna, R. A. and S. S. Shankarrao, "In vitro screening and molecular genetic markers associated with salt tolerance in maize", African Journal of Biotechnology, Vol. 12(27), pp 4251-4255, 2013.

[29] Pitzschke A., C. Forzani, H. Hirt, "Reactive oxygen species signaling in plants", Plant Signaling and Behavior, Vol. 8, pp 17571764, 2006.

[30] Gadallah M. A. A., "Effects of proline and glycinebetaine on Vicia faba responses to salt stress", Biologia Plantarum, Vol. 42, pp 249257, 1999. 